\title{
Science under the Nazis
}

\section{Robert P. Crease applauds the story of three great physicists who struggled to maintain their integrity during the Third Reich.}

$\mathrm{B}$ eware! This book is not what it seems. The subtitle suggests a black-andwhite tale of good and evil, to be read in detached comfort from high moral ground. Instead, science writer Philip Ball delivers an ambiguous yet moving saga of well-intentioned people compelled to act in "the grey zone between complicity and resistance". Its disturbing implications will leave attentive readers uneasy.

Ball follows the lives of three Nobel laureates under the Third Reich: Max Planck, Peter Debye and Werner Heisenberg. Planck was a humble member of the German intellectual elite who devoted himself to state service and, as head of the Kaiser Wilhelm Society (KWS), which promoted the natural sciences in Germany, was the titular representative of German science. Debye, a political and scientific pragmatist, was born in Maastricht, the Netherlands, but obtained nearly all his scientific training in Germany and professed himself culturally German. In 1934, he became director of the Kaiser Wilhelm Institute for Physics in Berlin. The ambitious and arrogant Heisenberg often acted as though he was the personification of German physics.

The disturbing saga begins in 1933, when Adolf Hitler was appointed Reich chancellor, paving the way for a totalitarian state. The Nazis increasingly forced Planck to use the KWS for political ends, such as by purging Jewish members - including Planck's friend Albert Einstein. Debye was coerced into a similar situation at the Kaiser Wilhelm Institute until he left for the United States in 1939. Heisenberg was a principal architect of the German atomic-bomb project. Ball traces how the Nazis ruthlessly exploited these and other scientists by preying on personal weaknesses and political naivety - citing "Debye's occasional self-interest and limited

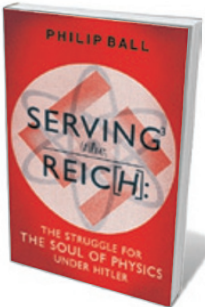

Serving the Reich: The Struggle for the Soul of Physics Under Hitler PHILIP BALL

Bodley Head: 2013.

moral engagement, Heisenberg's insecurity and egotism, Planck's prevarication and misconceived notion of duty" - to wheedle and compel them into actions that now look

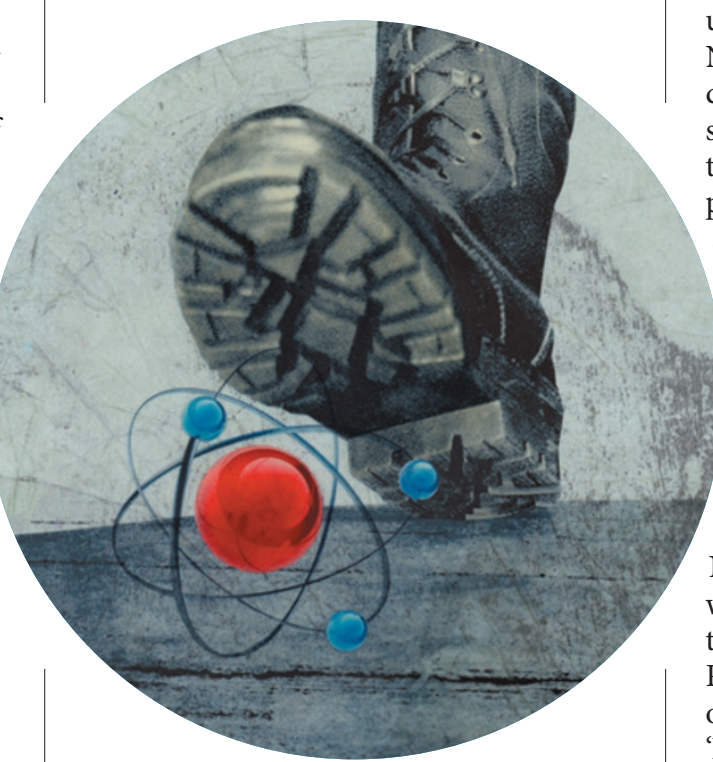

"disturbingly compliant" at best, and utterly immoral at worst.

Yet Ball does an outstanding service by reminding us how powerful and sometimes confusing the pressures were, and how it was not implausible to think that scientists could and should stay 'above politics'. Nazi tyranny and genocide were unprecedented, yet aspects of their programme seemed progressive, including their welfare and healthcare policies, and efforts to eliminate class differences. Moreover, the Nazi party was not monolithic, but comprised rival factions competing for Hitler's favours throughout the Reich, and was plagued by incompetent leaders and an inept bureaucracy. Many observers, inside Germany and out, including the three physicists in question, assumed not unreasonably that the Nazis would be forced to moderate their behaviour or lose power.

For these and other reasons, Ball writes, understanding moral behaviour under the Nazis is not "a matter of simply collating the documentary evidence and totting up episodes of compliance or resistance". He contends that we have to mine the ambiguous phrases and equivocal actions of scientists, and explore their inability to fathom their own motivations to reach a deeper understanding of their characters in a burgeoning atmosphere of paranoia and brutality.

Serving the Reich is packed with dramatic, moving and even comical moments. One is the harrowing story of Austrian-Jewish scientist Lise Meitner's escape from Germany in 1938. Her Nazi neighbour alerted the authorities, but word failed to reach the border patrol in time. More touching is an anecdote about Planck presiding at an official function and only managing to utter the abhorrent phrase 'Heil Hitler' on his third attempt. And Debye, anticipating that the Nazis would refuse to let him rename a science institute after Planck, carved Planck's name into the stone above the entrance. When ordered to remove it, Debye covered it with a wooden plank (the pun also works in German).

Ball recounts Heisenberg's famous visit to occupied Copenhagen in September 1941,

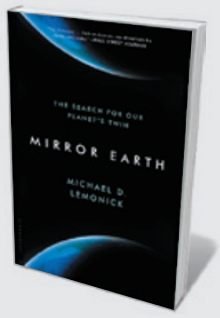

Mirror Earth: The Search for Our Planet's Twin Michael D. Lemonick (Bloomsbury, 2013) Science writer Michael Lemonick explores astronomers' interest in sister worlds. Focusing on NASA's Kepler space telescope, this book is studded with in-depth portraits of exoplaneteers such as David Charbonneau, hunter of super-Earths. (See Sara Seager's review: Nature 490,479; 2012.)

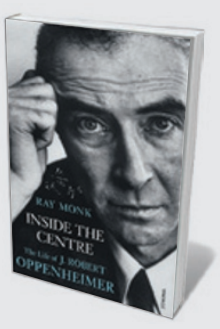

Inside the Centre: The Life of J. Robert Oppenheimer Ray Monk (Vintage, 2013)

This testimony to the triumphs and foibles of J. Robert Oppenheimer is illuminating. Ray Monk follows the physicist from adolescence to his role in the construction of the first atomic bomb. (See Istvan Hargittai's review: Nature 491, 670; 2012.) 
where he annoyed fellow scientists with his grandiosity. His self-delusion persisted: early in 1945, after a special allied mission had raced across a collapsing Germany to apprehend him, Heisenberg arrogantly assumed that he held a powerful bargaining position and evidently failed to grasp that he was a prisoner. When he heard that the United States had dropped an atomic bomb on Hiroshima, at first he refused to believe it, claiming that some "dilettante" American had to be bluffing.

Although such scenes make Serving the Reich a page-turner, Ball keeps the moral and existential ambiguities at the forefront. He lets us see that for many scientists, to abandon one's work and post - especially during such a crisis would seem "a dereliction of duty, not a moral act of protest". And defying the Nazis was not always an act of rebellion: Planck's insistence on holding a memorial in 1935 on the first anniversary of the Jewish scientist Fritz Haber's death was less a protest against anti-Semitism than an honour extended to a deceased, esteemed colleague.

But Ball has no sympathy for journalists who have bought scientists' self-serving apologies or condemned the scientists on the basis of cherry-picked evidence. Dutch journalist Sybe Rispens's 2006 accusation that Debye was a Nazi sympathizer, for instance, led the University of Utrecht in the Netherlands to drop the physicist's name from its nanomaterials institute.

Ball insists that, rather than simplistically condemning or absolving the German scientists, we should look at their moral behaviour as a perpetually open question. Most daringly, he suggests that the way they coped with entanglements of science, politics and life is still representative of scientists now. By the end of this book, careful readers will be left with the queasy feeling that our own moral high ground has disappeared, and that Ball has revealed the 'soul' of physics to be no more intrinsically noble than any other.

Robert P. Crease is professor of philosophy at Stony Brook University, New York, and author of World in the Balance. e-mail:robert.crease@stonybrook.edu

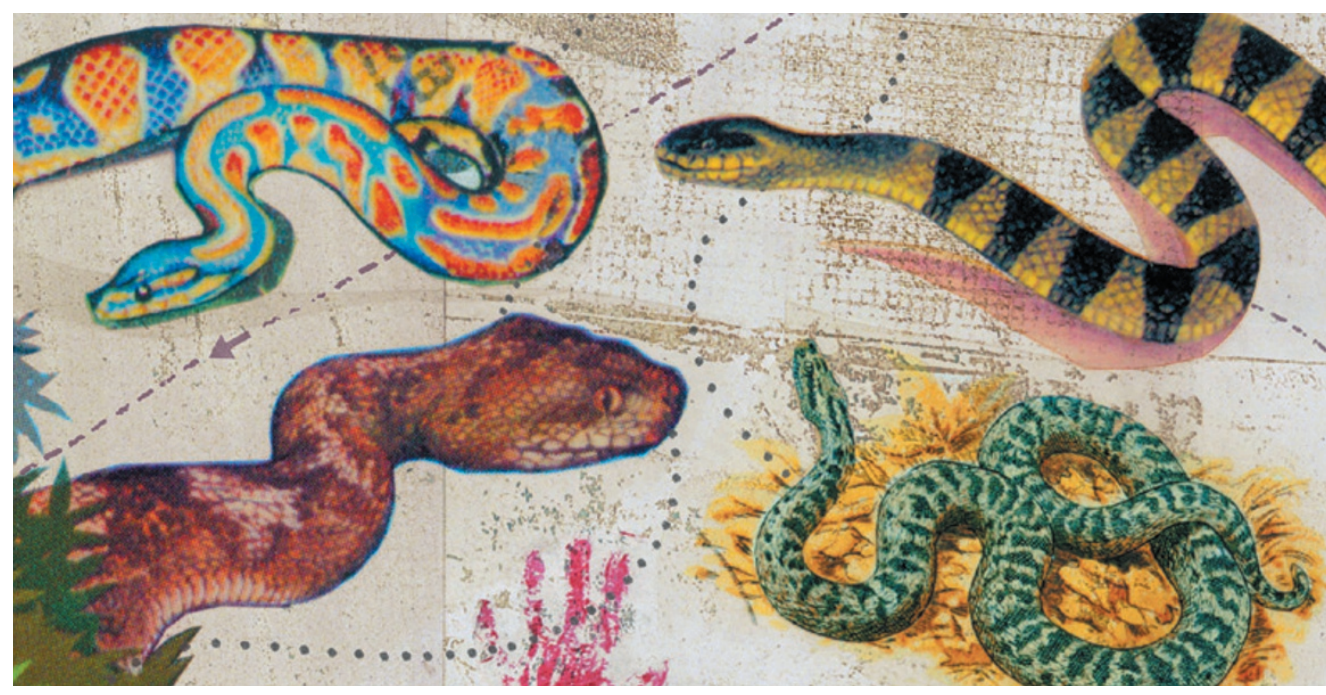

BIOLOGY

\section{The love of pit vipers}

\section{Stuart Pimm follows a fellow biologist's evolution from wide-eyed wonder to a life chasing snakes in the field.}

I shake the hand of my fellow guide on a tour group along the Amazon. Feeling missing fingers, I blurt out, "You're a herpetologist?" Quickly forgiving me, he names the species of snake responsible. Harry Greene, in his engaging autobiography Tracks and Shadows, tells us of others who have lost digits. Greene himself still has a full set. He has been lucky - and careful.

We learn much about snakes from Greene, but more about the academic lineages and personalities that shaped his field. Greene and I are academic cousins, sharing a distant academic ancestor in the form of field biologist Joseph Grinnell, who worked at the University of California, Berkeley, from 1908 until his death in 1939. The theme of Greene's book is that the shadows cast by academic family mould our lives, but so do the species we track.

The field guide is the beginning. I vividly remember getting my first. It had to be of birds (my lifelong passion), because all Britain's amphibians and reptiles would form a

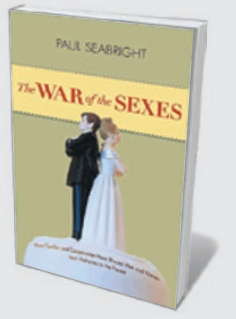

The War of the Sexes: How Conflict and Cooperation Have Shaped Men and Women from Prehistory to the Present

Paul Seabright (Princeton University Press, 2013)

An economist examines animals' tactics for ensuring reproduction, and ponders how human evolution can explain gender inequities in the West. (See John Whitfield's review: Nature 484, 317; 2012.)

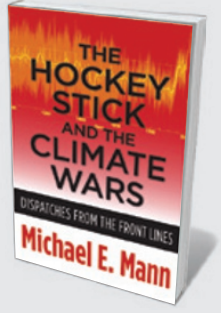

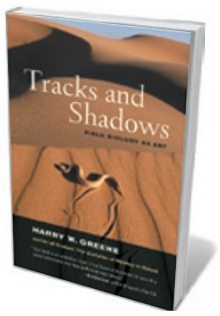

Tracks and Shadows: Field Biology as Art HARRY W. GREENE University of California Press: 2013. him thinking, "I want to see that one. No, that's the one I just have to find!" And although the taxa differed, the experiences and outcomes were the same: we had to find what we saw that so intrigued us.

Two things follow. Soon, you are looking in places where you might find the real thing. Creeks, wetlands, woodlots and barren land - all places others might pass Only in graduate school in the Ameritaxonomic passion was set, did I meet the groundbreaking guides to America's exceptional diversity of amphibians and reptiles by Robert Stebbins and Roger Conant. Greene flips through Conant's pages, and I imagine small volume indeed. can West, when my e (n) (n)

(n)

(n)

\section{The Hockey Stick and the Climate Wars:} Dispatches from the Front Lines Michael E. Mann (Columbia University Press, 2013) Meteorologist Michael Mann recounts the attack on his seminal 1998 global warming paper. The lengths to which deniers have gone to discredit the research continue to astound. (See Simon Lewis' review: Nature 483, 402-403; 2012.) 